Article

\title{
Statistical Approach for Assessing the Suitability of Substrates for a Biogas Plant
}

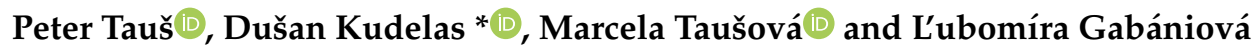 \\ Institute of Earth Resources, Faculty of Mining, Ecology, Processing Control and Geotechnology, \\ Technical University of Kosice, 04001 Kosice, Slovakia; peter.taus@tuke.sk (P.T.); marcela.tausova@tuke.sk (M.T.); \\ lubomira.gabaniova@tuke.sk (L'.G.) \\ * Correspondence: dusan.kudelas@tuke.sk
}

Received: 29 September 2020; Accepted: 28 October 2020; Published: 30 October 2020

\begin{abstract}
In this paper, we focused on the statistical evaluation of inputs to a biogas plant processing a mixture of kitchen waste and agricultural crops to ensure stable biogas production. The aim of the research was to identify the components of the input substrates that will ensure the maximum yield of $\mathrm{CH}_{4}$ and the substrates that increase the production of $\mathrm{H}_{2} \mathrm{~S}$. By a suitable combination of substrates, it is possible to optimize the production of biogas from the biogas plant. We analyzed a sample of 858 measurements, which were carried out in a selected biogas station for a period of 2.5 years. We were interested in differences in production of $\mathrm{CH}_{4}, \mathrm{O}_{2}$, and $\mathrm{H}_{2} \mathrm{~S}$ outputs depending on the composition of inputs. From 17 inputs, 125 substrates were formed. The significance of the influence of individual substrates as categorical variables with the achieved numerical values was assessed by means of ANOVA analysis. Selected substrates were sorted based on $\mathrm{CH}_{4}$ and $\mathrm{H}_{2} \mathrm{~S}$ production using graphical methods (bubble graphs) into four quadrants defining the desired and undesired values of the output variables. We identified a total of 20 suitable and 11 unsuitable substrates to produce quality biogas. Sorghum silage substrate was defined as a substrate that significantly increases the proportion of $\mathrm{H}_{2} \mathrm{~S}$ in biogas.
\end{abstract}

Keywords: biogas plant; input substrates; biogas; methane production; biowaste

\section{Introduction}

The use of renewable energy sources is currently a frequently discussed topic. It is generally considered that their main advantage is the reduction in the use of fossil fuels and their environmental impact. The problem of using renewable energy sources is their variability and, therefore, frequent dependence on climatic conditions. Biogas, which is the product of anaerobic fermentation of organic material, has the advantage of being a gas that can be stored in storage tanks and can be used at the time of need. Biogas is used to generate electricity, heat, fuel for cars or in technologies using the synergistic effect of biogas and other energy sources, such as water, wind, sun.

Biogas production in the European Union increased due to encouraging of renewably energy policies. The EU reached production levels of 18 billion $\mathrm{m}^{3}$ methane in 2015, which is equal to half of the global biogas production. In biogas electricity production, the EU is a leader with more than $10 \mathrm{GW}$ installed output and around 17,400 biogas plants. Half of all biogas consumption was destined to heat generation: 127 TJ of heat and 61 TWh of electricity in 2015 [1]. In the Czech Republic, Denmark, Germany, Italy, Austria and Greece, biogas from anaerobic digesters predominates; meanwhile in Estonia, Ireland, Portugal, and United Kingdom, landfill biogas dominates the market. Biogas from wastewater treatment prevails in few countries, such as Lithuania, Poland, and Sweden [2].

In 2017, 351 new biogas plants were added to the EU. In the countries of the Visegrád Four, the development of biogas plants has occurred, especially in recent years. As of 31 December 2019, 
there were 574 biogas plants in the Czech Republic with an installed capacity of $367 \mathrm{MW}$. The amount of electricity produced from these was 2526 GWh and the share of biogas in Renewable Energy Sources (RES) was $22.9 \%$. There are currently 308 biogas plants in Poland and 81 in Hungary; no further data have been found $[3,4]$.

In the last decade, the market for renewable energy sources in Slovakia has grown significantly. This was reflected, for example, in the fact that investments in biogas plants were more strongly promoted, especially until 2013, when 41 were added. In 2014, no station was put into operation, which was caused by the decisions of energy distribution companies. Last year (2019) a call was launched for further biogas plant projects [5].

A total of 108 biogas plants with an output of approximately $103 \mathrm{MW}$ and a planned annual production of 810,526 MWh of electricity are currently connected in Slovakia. Most of these stations have an installed capacity in the range of 0.9-1 MW. The facilities in Badín (7.03 MW, KOMPALA, a.s.), Bošany (2.83 MW, Alternative Energy, s.r.o.), Dubník (AT GEMER, s.r.o.), Rozhanovce, and Plavnica (each $1 \mathrm{MW}$ ) have the highest output. For comparison, Germany has about 9000 biogas plants with an installed capacity of about 0.4 MW, which allows them to use waste material more consistently [6,7].

Biogas consists of methane $\left(\mathrm{CH}_{4}\right)$ in the range of $50-70 \%$ and carbon dioxide $\left(\mathrm{CO}_{2}\right)$ at a concentration of 30-50\%. Nitrogen $\left(\mathrm{N}_{2}\right)$ represents $0-3 \%$, water vapor $\left(\mathrm{H}_{2} \mathrm{O}\right) 5-10 \%$, oxygen $\left(\mathrm{O}_{2}\right)$ at a concentration of $0-1 \%$, and hydrogen sulfide $\left(\mathrm{H}_{2} \mathrm{~S}\right)$ at a concentration of $0-10,000$ ppmv. Other gases are represented in a small number of ppmv. The exact composition of biogas depends on the type of input substrate. Except for $\mathrm{CH}_{4}$, all other ingredients are undesirable [8]. The methane energy content characterized by the lower calorific value (LCV) is $50.4 \mathrm{MJ} / \mathrm{kg} \mathrm{CH}_{4}$ or $36 \mathrm{MJ} / \mathrm{m}^{3} \mathrm{CH}_{4}$ (at sewage treatment plant (STP) conditions). The higher the $\mathrm{CO}_{2}$ or $\mathrm{N}_{2}$ content, the lower the biogas value. For biogas with a methane content of $60-65 \%$, the LCV is approximately $20-25 \mathrm{MJ} / \mathrm{m}^{3}$. $\mathrm{H}_{2} \mathrm{~S}_{\text {and }} \mathrm{NH}_{3}$ are toxic, explosive, and extremely corrosive, damaging the combined heat and power (CHP) unit (engine) and metal parts by $\mathrm{SO}_{2}$ emissions from combustion [9-12]. By desulfurizing biogas, we can extend the life of steel parts of the structure [13]. In addition, bacteria which form hydrogen sulfide compete with methane-forming bacteria for the same substrate [14]. The presence of siloxanes in biogas, even in small concentrations, causes silicone oxides to form sticky residues during combustion, which are deposited in biogas internal combustion engines and in valves causing malfunctions [10].

The feedstock to produce biogas in biogas plants is the biomass of organic origin of plant or animal origin. The most commonly used types of substrates are specifically grown biomass (maize, beet, haylage), biowaste from public greenery maintenance, biowaste with households and gardens, food and biowaste from supermarkets, residues from canteens, restaurants and hotels, biowaste from business operations (bakeries, distilleries), breweries, sugar refineries, meat processing plants), farm animal waste (manure, liquid manure, litter), municipal and domestic waste, and sewage sludge [15]. Due to BIO stream in the world, which is growing every day, the volume of biodegradable polylactic acid in waste has increased significantly. Its presence in biowaste could increase biogas production, but with some limitations. The time needed for the maximal biogas production was almost 40 days in thermophilic conditions (separate digesters could be required) and 280 days for mesophilic conditions (which is not acceptable in technical scale) [16].

The operation of biogas plants is overly sensitive to the mix of substrates used. Selection and optimization of the mixture are, therefore, an important task of effectively operating or planning such devices [17]. There are models like the Anaerobic Digestion Model No.1 (ADM1) that allow calculating a good prediction of the biogas plant output based on the substrates used.

Optimizing the operation of biogas plants is and will be one of the major challenges for anaerobic digesting (AD) in the near future. Due to the cost of the substrate, only optimally operated biogas plants will be economically viable [18]. Successful utilization of organic fractions of municipal solid wastes for biogas production is fundamental for process stability in AD and addition of non-activated or activated hydrochars into its reactors improved their digestibility. Activated hydrochars derived from coffee ground biomass in reactor increase biogas production around $5 \%$ and are more effective in 
chemical oxygen demand, dissolved organic carbon and organic acids removal [19]. ADM1 is both exceedingly popular and the latest, most comprehensive mathematical model used to simulate the anaerobic digestion process. ADM1 is a structured model that includes the steps of disintegration and hydrolysis, acidogenesis, acetogenic, and methanogenesis. The ADM1 system is implemented as a differential equation system in the MATLAB ${ }^{\circledR}$ toolbox for modelling, optimizing, and controlling a biogas plant [20]. ADM1 includes a simulation of biogas plant operation, including heat and electricity, as well as models for performance and stability criteria, including costs versus benefits, the stability of substrate degradation processes and operating constraints such as upper and lower $\mathrm{pH}$ limits, maximum volatile fatty acidity and total alkalinity (VFA/TA) [21], maximum solids content in the hood and minimum methane concentration in biogas.

Substrate mixtures were also optimized using Genetic Algorithm and Optimization of Particle Swarm [22]. Ziegenhirt et al. [23] used procedures such as Covariance Matrix Adaption Evolution Strategy (CMAES) [24,25] or Differential Evolution (DE) [26] to reduce the number of simulations needed. The parameter optimization tool (SPOT) [27] was also used.

There are also alternative modelling techniques. A rough performance estimate can be determined based on the biogas potential of the substrates used and their associated costs. This additional knowledge can be integrated into the optimization process through the quality of the selected surrogate modelling technique. This approach of integrating different levels of granularity or cost was formerly called multi-fidelity optimization [28].

One of the models is the Kriging, which is a particular model for continuous smooth problems. In addition to its predictive performance, it is often used because it provides an estimate of the local certainty of the model that can be used to calculate the expected improvement (EI) of a new sample [29,30]. Jones et al. [31] introduced this concept to balance usage and exploration in costly optimization, with the term Effective Global Optimization (EGO). Other models include Artificial Neural Networks (ANN), Support Vector Regression (SVR) [32], Random Forest (RF) [33] or Multivariate Adaptive Regression Splines (MARS) [34].

$\mathrm{H}_{2} \mathrm{~S}$ removal has become an important subject of research in many studies focused on the effective benefits that bring in real conditions of operation of biogas plants (economic, technological, environmental). We know the physical-chemical and biotechnological methods of $\mathrm{H}_{2} \mathrm{~S}$ removal, however biotechnological ones have become more attractive in recent years due to higher efficiency (> 99\%) and lower operating costs, and they do not produce secondary streams [35,36].

Physical-chemical methods include, for example, water scrubbing (at $\mathrm{H}_{2} \mathrm{~S}$ concentrations 300-2500 ppmv, methane purity is 95-98\%), physical organic scrubbing (methane purity is 93-98\%), chemical absorption (methane purity is $>98 \%$ ), pressure swing adsorption (PSA, methane purity is $96-98 \%$ ), and membrane and cryogenic separation (methane purity is $90-96 \%$ and $99 \%$ ) [37].

Biotechnological methods are divided into in situ (addition of $\mathrm{H}_{2}$ to the liquid phase of the reactor) and ex situ methods (addition of $\mathrm{CO}_{2}$ and $\mathrm{H}_{2}$ from an external source with hydrogenotrophic microbes). [36] The purity of $\mathrm{CH}_{4}$ depends on the type of reactor, raw material, temperature, and retention time, and ranges from $60 \%$ (in situ, continuous reactor, chicken manure, 10 days) [36] to $100 \%$ (in situ, continuous-flow stirred tank reactor (CSTR), biogas sludge, $38^{\circ} \mathrm{C}, 20$ days) [38].

The influence of control factors on the performance of biogas treatment evaluated by ANOVA was used, for example, by Marin and Vega [39], Armah and Chetty [40], Marin and Carmona-Martínez [41], Jamaluddin [42], etc.

In our research, we focused on the statistical assessment of inputs to the biogas plant to ensure stable methane production, because of significant problems with corrosivity of the engine. The aim of our research was to maximize the amount of $\mathrm{CH}_{4}$ in biogas, minimize the amount of $\mathrm{H}_{2} \mathrm{~S}$, and ensure the stability of biogas production to protect the technology of the biogas plant and increase its effectivity and performance. We chose this biogas plant because the operator approached us with a request to assess the impact of feedstock on biogas quality. In Slovakia it is still common practice to install refurbished technologies to reduce investment costs. Cogeneration units used at such biogas plants are 
extremely sensitive to the increased $\mathrm{H}_{2} \mathrm{~S}$ content in biogas. This is reflected in the increased corrosivity of machine parts and the need for frequent service breaks of cogeneration units. The operator of this biogas plant does not use a dose optimization calculator. The reason is that the main input raw material is waste from various food operations in the catchment area. This results in a difficult prediction of specific volumes and quantities. Inputs with a positive effect on $\mathrm{CH}_{4}$ production will allow the operator to replace the input raw material producing larger amounts of $\mathrm{H}_{2} \mathrm{~S}$.

\section{Methods and Methodology}

The analysis itself was performed based on measured data of a specific biogas plant, while the input components of individual substrates were recorded and subsequently the achieved values of $\mathrm{CH}_{4}, \mathrm{H}_{2} \mathrm{~S}$, and $\mathrm{O}_{2}$ were measured. At the beginning, we started from a sample of 858 measurements, which were carried out in a selected biogas station in the period from 1 May 2015-30 October 2017. The data processed the ratio of the input components of the substrate: corn silage, sorghum silage, receiving tank, bread, rye, manure, oil, juniper, haylage, chopped (maize silage), corn cob mix (CCM), pasteurized biodegradable waste, fruit, vegetables, other $(1,2,3,4)$, and the ratio of outputs from the biogas plant in $\%-\mathrm{CH}_{4}, \mathrm{O}_{2}, \mathrm{H}_{2} \mathrm{~S}$ (see Table 1). A total of 73 data were excluded during data validation due to various meter failures and on-site service work.

Table 1. Basic descriptive statistical analysis of research input variables.

\begin{tabular}{clccccc}
\hline Num. & \multicolumn{1}{c}{ Folder } & N & Mean & Std. Dev. & Minimum & Maximum \\
\hline 1 & Corn silage/Maize silage [kg] & 775 & $28,358.10$ & 7392.65 & 1500 & 39,860 \\
2 & Sorghum silage [kg] & 155 & 8258.97 & 4496.66 & 1000 & 17,800 \\
3 & Receiving tank [kg] & 492 & $15,634.3$ & 6102.37 & 1000 & 34,000 \\
4 & Pastry [kg] & 191 & 1155.76 & 770.8 & 100 & 4000 \\
5 & Rye [kg] & 94 & $10,245.4$ & 2933.97 & 1540 & 17,580 \\
6 & Manure [kg] & 408 & 1562.55 & 571.93 & 0 & 2660 \\
7 & Oil [kg] & 147 & 276.74 & 158.13 & 0 & 820 \\
8 & Juniper [kg] & 88 & 3649.77 & 2192.42 & 300 & 6880 \\
9 & Other 1 [kg] & 189 & 3198.52 & 2868.25 & 60 & 15,000 \\
10 & Other 2 [kg] & 210 & 1981.86 & 1890.45 & 60 & 20,000 \\
11 & Others 3 [kg] & 82 & 1830.00 & 2535.58 & 50 & 10,700 \\
12 & Others 4 [kg] & 6 & 2573.33 & 2009.25 & 600 & 6300 \\
13 & Haylage [kg] & 180 & 5321.89 & 2436.56 & 200 & 12,000 \\
14 & Corn chips silage [kg] & 26 & $27,173.1$ & 8368.92 & 6000 & 40,000 \\
15 & CCM (Corn Cob Mix) [kg] & 23 & 2135.65 & 1075.19 & 1020 & 4740 \\
16 & Pasteurized biodegradable waste [kg] & 240 & $13,727.00$ & 6519.78 & 0 & 36,600 \\
17 & Fruits/vegetables [kg] & 236 & 2971.50 & 1341.05 & 230 & 6320 \\
$\#$ & CH $[\%]$ & 785 & 59.53 & 2.92 & 43.3 & 67.5 \\
$\#$ & O2 [\%] & 781 & 0.16 & 0.22 & 0 & 5.7 \\
$\#$ & H S [\%] & 785 & 0.10 & 0.09 & 0 & 0.76 \\
\hline
\end{tabular}

Note: \# biogas plant outputs.

Within further processing we were interested in differences in production of $\mathrm{CH}_{4}, \mathrm{O}_{2}, \mathrm{H}_{2} \mathrm{~S}$ outputs depending on the composition of inputs. Since the substrates were composed of 17 components in different structures, we created groups of substrates with the same combination of input variables. The individual input components were numbered from 1-17 and depending on whether the component was present in the substrate, the given number was assigned to the substrate designation, creating 125 substrate combinations (see Figure 1).

The significance of the influence of individual substrates as categorical variables on the achieved numerical values of $\mathrm{CH}_{4}$ and $\mathrm{H}_{2} \mathrm{~S}$ was assessed by ANOVA analysis (one-way ANOVA), which was subsequently verified. Our goal was to assess whether there was a statistically significant impact. To verify the results, we supplemented the analysis with a nonparametric Wilcoxon variability test, which confirmed the results of a one-way ANOVA. 


\begin{tabular}{l|r}
\hline Level & Count \\
\hline Total & 858 \\
\hline $1-2-3--6-------$ & 88 \\
$1--3--6---13----$ & 58 \\
$1--3--6------$ & 43 \\
\hline $1--3--56------$ & 42 \\
\hline $1---4-10-----16-17$ & 42 \\
$1---10-----16-17$ & 34 \\
$1-2-3--67-------$ & 28 \\
$1--3--67---13---$ & 23 \\
$1---910-----16-17$ & 23 \\
$1---------16-17$ & 22 \\
$11--3--67-------$ & 19 \\
$1---4-910-----16-17$ & 18 \\
$1----11-----16-17$ & 14 \\
$1--3-4-910-------$ & 13 \\
$1--3--910------$ & 13 \\
$1--3--9-------$ & 12 \\
$1---4------16-17$ & 12 \\
$1--3--567------$ & 11 \\
$1--3-------$ & 10 \\
$1----910-11-----16-17$ & 10 \\
$1--3-4-6---13----$ & 9 \\
$1--4-910-11----16-17$ & 9 \\
$1---10-11----16-17$ & 8 \\
$1-2-3--678---13----$ & 8 \\
$1-2-3--68------$ & 8 \\
$1-2---6------$ & 8 \\
\hline
\end{tabular}

\begin{tabular}{|c|c|}
\hline Level & Count \\
\hline $1--3-4-68---13----$ & 8 \\
\hline 1--3--789---13---- & 8 \\
\hline $1--9-11--16-17$ & 8 \\
\hline $1-\ldots-16-$ & \\
\hline $1-2-3--56------$ & 7 \\
\hline $1--3-4-67---13----$ & 7 \\
\hline $1--3--5--\cdots$ & \\
\hline 1----9------16-17 & 7 \\
\hline $1--3-4------$ & 6 \\
\hline 1--3-4-678---13---- & 6 \\
\hline $1--4-9----16-17$ & 6 \\
\hline $1--3--68---13---$ & 5 \\
\hline 1---4-910-11-----16- & 5 \\
\hline 1---4-9-11-----16- & 5 \\
\hline $1----56------$ & \\
\hline $\begin{array}{l}-17 \\
1---10-11----16\end{array}$ & 4 \\
\hline $1-\cdots-10----17$ & 4 \\
\hline $1-2--\ldots--$ & 4 \\
\hline $1-2-3-4-6---13----$ & 4 \\
\hline 1--3--6789---13---- & 4 \\
\hline $1---4-10-11-----16-17$ & 4 \\
\hline $1--4--11----16-17$ & 4 \\
\hline $1---58------$ & 4 \\
\hline 1----910------16- & 4 \\
\hline $1---9-11-\cdots--17$ & 4 \\
\hline
\end{tabular}

Figure 1. Substrate combination.

In addition to the high variability of the achieved outputs due to the type of substrate, significant differences in the range of the values were found with the calculation of the standard deviation of the outputs according to the substrate. This fact affects the stability in the prediction of biogas and $\mathrm{H}_{2} \mathrm{~S}$ production. Of the total of 125 substrates, those that achieved relatively stable output values were selected, making it possible to predict outputs with higher reliability. This selection was made by means of the standard deviation indicator, with the substrates having the lowest values of this indicator being selected. This gave 63 substrates. Subsequently, the selected substrates were sorted, based on $\mathrm{CH}_{4}$ and $\mathrm{H}_{2} \mathrm{~S}$ production, into four quadrants using graphical methods (bubble graphs) delimiting the desired and undesired values of the output variables. We identified suitable and unsuitable substrates. Finally, by comparing the structure of these substrates, we defined the key components most significantly influencing the improvement/worsening of the outputs.

\section{Results}

\subsection{Analysis of Variability of $\mathrm{CH}_{4}$ and $\mathrm{H}_{2} \mathrm{~S}$ Production from Individual Substrates}

The collected data were first sorted according to the occurrence of the input components into 125 substrates (see Figure 1). Subsequently, the statistical significance of the effect of the substrate on achieving $\mathrm{CH}_{4}$ and $\mathrm{H}_{2} \mathrm{~S}$ production was examined.

Analysis of variability of $\mathrm{CH}_{4}$ production by one-way ANOVA method confirmed statistically significant influence of individual substrates on the achieved values. A statistically significant variability in $\mathrm{CH}_{4}$ production was demonstrated, with values ranging from $49-67.5 \%$ with an average of $59.5 \%$ (see Figure 2). This was verified and subsequently confirmed by a non-parametric Wilcox variability test. The subject of further investigation will be the delineation of substrates with above-average values of the investigated indicator.

The analysis of variability also in the case of $\mathrm{H}_{2} \mathrm{~S}$ production by one-way ANOVA confirmed a statistically significant influence of individual substrates on the achieved values. A statistically significant variability in $\mathrm{H}_{2} \mathrm{~S}$ production was demonstrated with values ranging from $0-0.75 \%$ with an average of $0.1 \%$ (see Figure 3 ). The nonparametric Wilcox variability test also confirmed these findings in this case. The subject of further investigation will be the laying out of substrates with the lowest values of the studied indicator. 


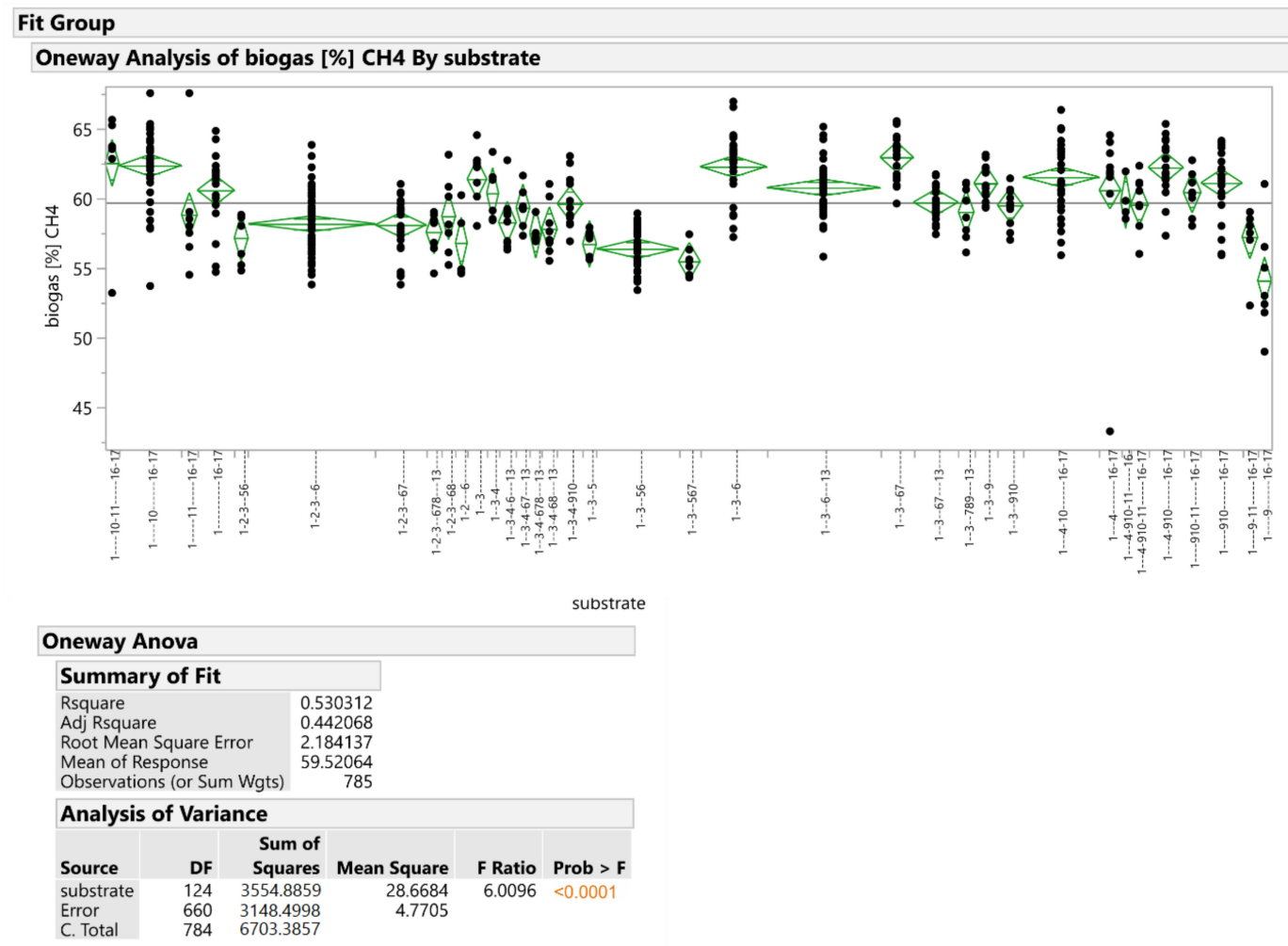

Figure 2. Analysis of variance of $\mathrm{CH}_{4}$.

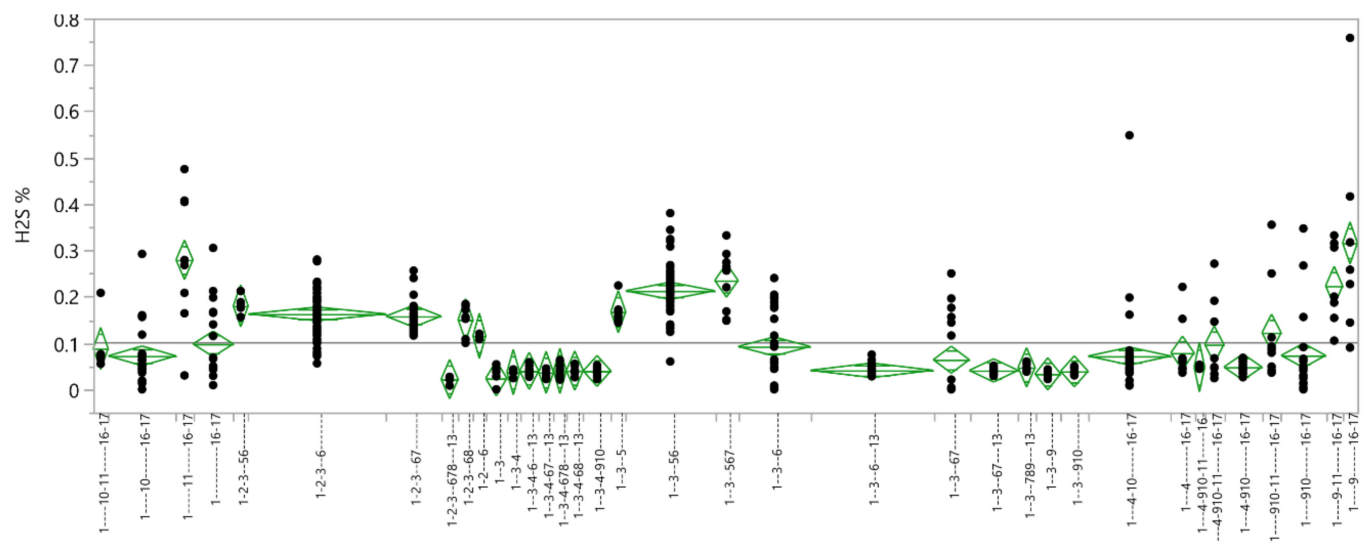

bstrate

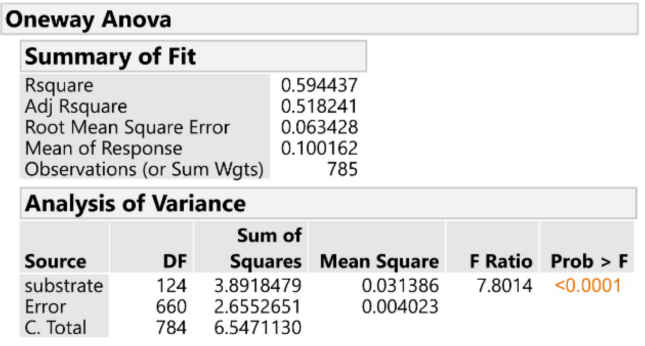

Figure 3. Analysis of variance of $\mathrm{H}_{2} \mathrm{~S}$. 


\subsection{Selection of Substrates with Stable Production}

Based on this, we decided to investigate which substrates achieved the desired values of the output variables (i.e., high $\mathrm{CH}_{4}$ values and low $\mathrm{H}_{2} \mathrm{~S}$ values). In more detail, we observed a high variance of values at the level of individual substrates, which reduces the reliability of subsequent deductions.

To increase the accuracy of the following predictions, it was necessary to select from all 125 substrates those that achieved relatively stable output values. This selection was made by means of a standard deviation indicator within each substrate, and the substrates with the lowest values of this indicator were selected. The calculated values were in the interval: standard deviation $\mathrm{H}_{2} \mathrm{~S}<0 ; 0.22>$; standard deviation $\mathrm{CH}_{4}<0 ; 5.85>$ (see Figure 4).

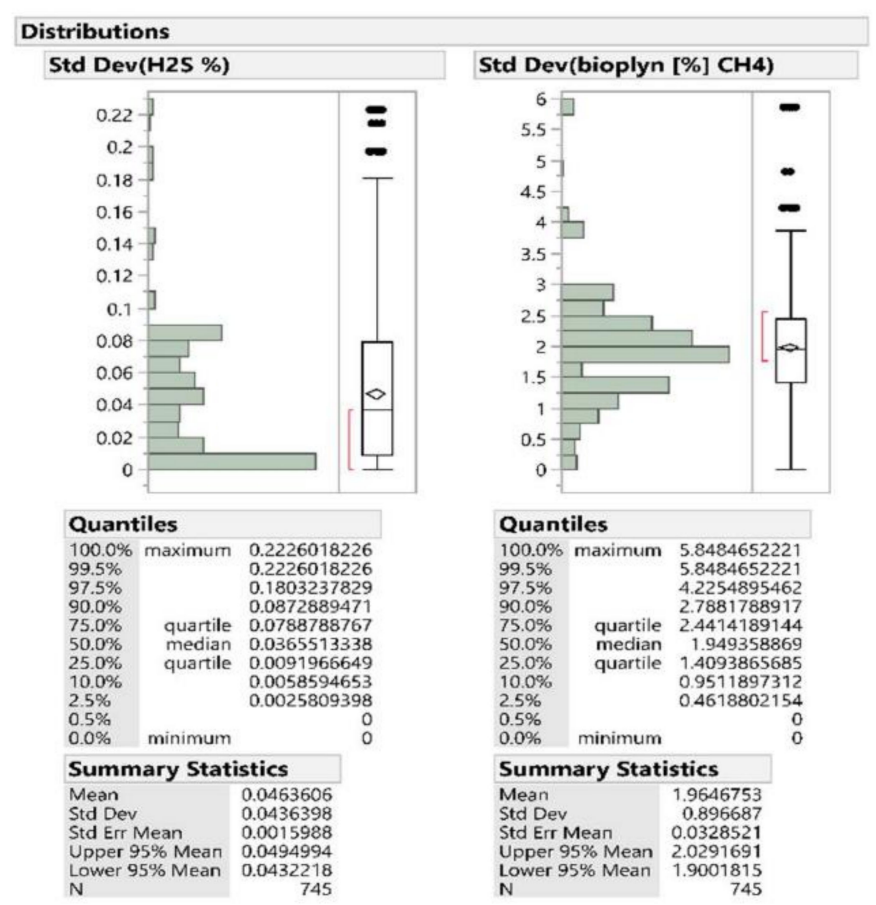

Figure 4. Standard deviation distributions of $\mathrm{H}_{2} \mathrm{~S}$ and $\mathrm{CH}_{4}$.

When selecting stable substrates, we chose the standard deviation indicator $\mathrm{H}_{2} \mathrm{~S}$, as the values of this indicator are crucial for improving the quality of biogas. The selection limit was set at 0.05 , covering more than half of the measurements (see Figure 5). By selecting all substrates with a standard deviation of the $\mathrm{H}_{2} \mathrm{~S}$ indicator up to 0.05 , all stable substrates were marked with a red asterisk; at the same time we can observe how stable the given substrates are in terms of standard deviation $\mathrm{CH} 4$, marked with a blue asterisk.

446 measurements from the original 785 were selected. These measurements represent 63 relatively stable substrates. Thanks to the selection, we managed to reduce the standard deviation of $\mathrm{H}_{2} \mathrm{~S}$ by almost half (see Table 2).

Table 2. Univariate simple statistics after excluding unstable substrates.

\begin{tabular}{cccccc}
\hline & N & Mean & Std. Dev. & Minimum & Maximum \\
\hline $\mathrm{CH}_{4}[\%]$ & 446 & 59.30 & 2.39 & 53.50 & 65.9 \\
$\mathrm{H}_{2} \mathrm{~S}[\%]$ & 446 & 0.08 & 0.06 & 0.00 & 0.28 \\
\hline
\end{tabular}




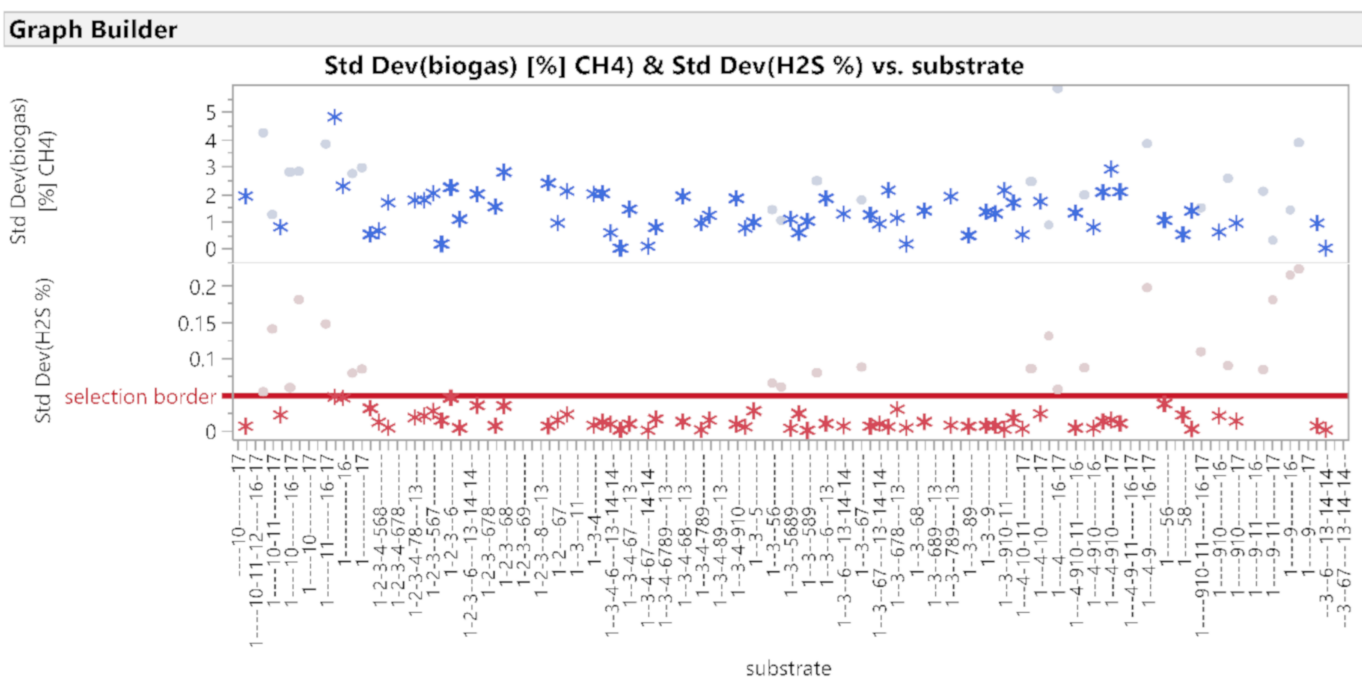

Figure 5. Analysis of the standard deviation of $\mathrm{CH}_{4}$ and $\mathrm{H}_{2} \mathrm{~S}$.

\subsection{Assessment of Substrate Quality}

Substrate selection presented in the previous analysis was subsequently analyzed for the $\mathrm{CH}_{4}$ and $\mathrm{H}_{2} \mathrm{~S}$ output variables achieved (Figure 6). Four quadrants were defined:

I. Quadrant with $\mathrm{CH}_{4}$ value greater than $60 \%$ and $\mathrm{H}_{2} \mathrm{~S}$ value less than $0.125 \%$.

II. Quadrant with $\mathrm{CH}_{4}$ greater than $60 \%$ and $\mathrm{H}_{2} \mathrm{~S}$ greater than $0.125 \%$.

III. Quadrant with $\mathrm{CH}_{4}$ less than $60 \%$ and $\mathrm{H}_{2} \mathrm{~S}$ less than $0.125 \%$.

IV. Quadrant with $\mathrm{CH}_{4}$ less than $60 \%$ and $\mathrm{H}_{2} \mathrm{~S}$ greater than $0.125 \%$.
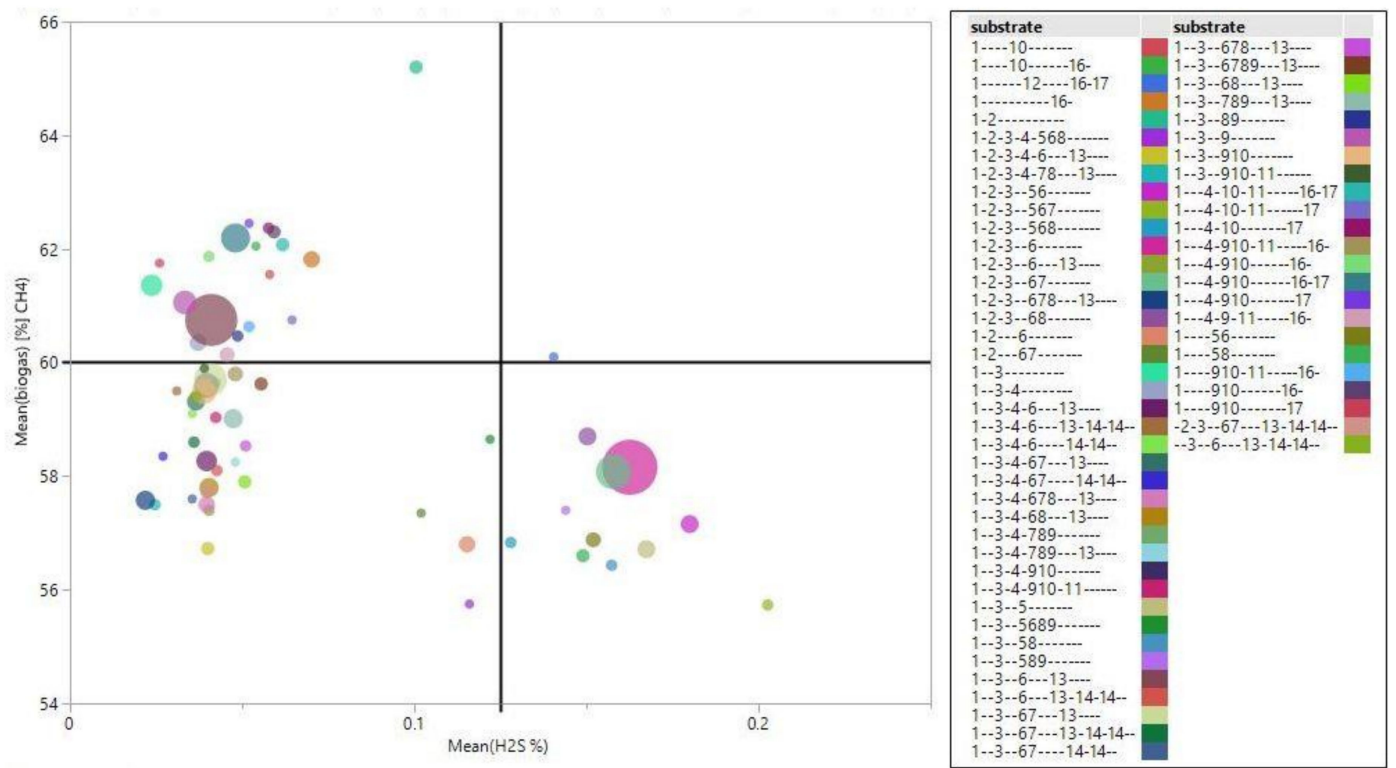

Figure 6. Definition of substrate evaluation quadrants based on $\mathrm{H}_{2} \mathrm{~S}$ a $\mathrm{CH}_{4}$.

Our aim was to divide substrates into suitable and unsuitable on the basis of the required values of the output variables. The best quality substrates are those with $\mathrm{CH}_{4}$ at $60 \%$ higher and $\mathrm{H}_{2} \mathrm{~S}$ below $0.125 \%$, indicated by quadrant I. The least suitable substrates belong to quadrant IV with $\mathrm{CH}_{4}$ values below $60 \%$ and $\mathrm{H}_{2} \mathrm{~S}$ values above $0.125 \%$. 


\subsection{Suitable Substrates}

On this basis, it was possible to select substrates with the highest quality in our case 20 substrates located in quadrant I (Figure 7). The figure shows the position of the substrates in terms of the achieved values of $\mathrm{CH}_{4}$ (y-axis) and $\mathrm{H}_{2} \mathrm{~S}$ (x-axis) production. The size of the bubble expresses the occurrence of such a substrate within the analyzed period of two years. As we can see, the most common substrate was 1-3-6-13, which produced an average of $61 \% \mathrm{CH}_{4}$ and $0.04 \% \mathrm{H}_{2} \mathrm{~S}$. At the same time, we see here that the best (highest) value of $\mathrm{CH}_{4}$ was achieved by the substrate 1-2- at the level of $65 \%$ and the best (lowest) value of $\mathrm{H}_{2} \mathrm{~S}$ was achieved by the substrate 1-3-.

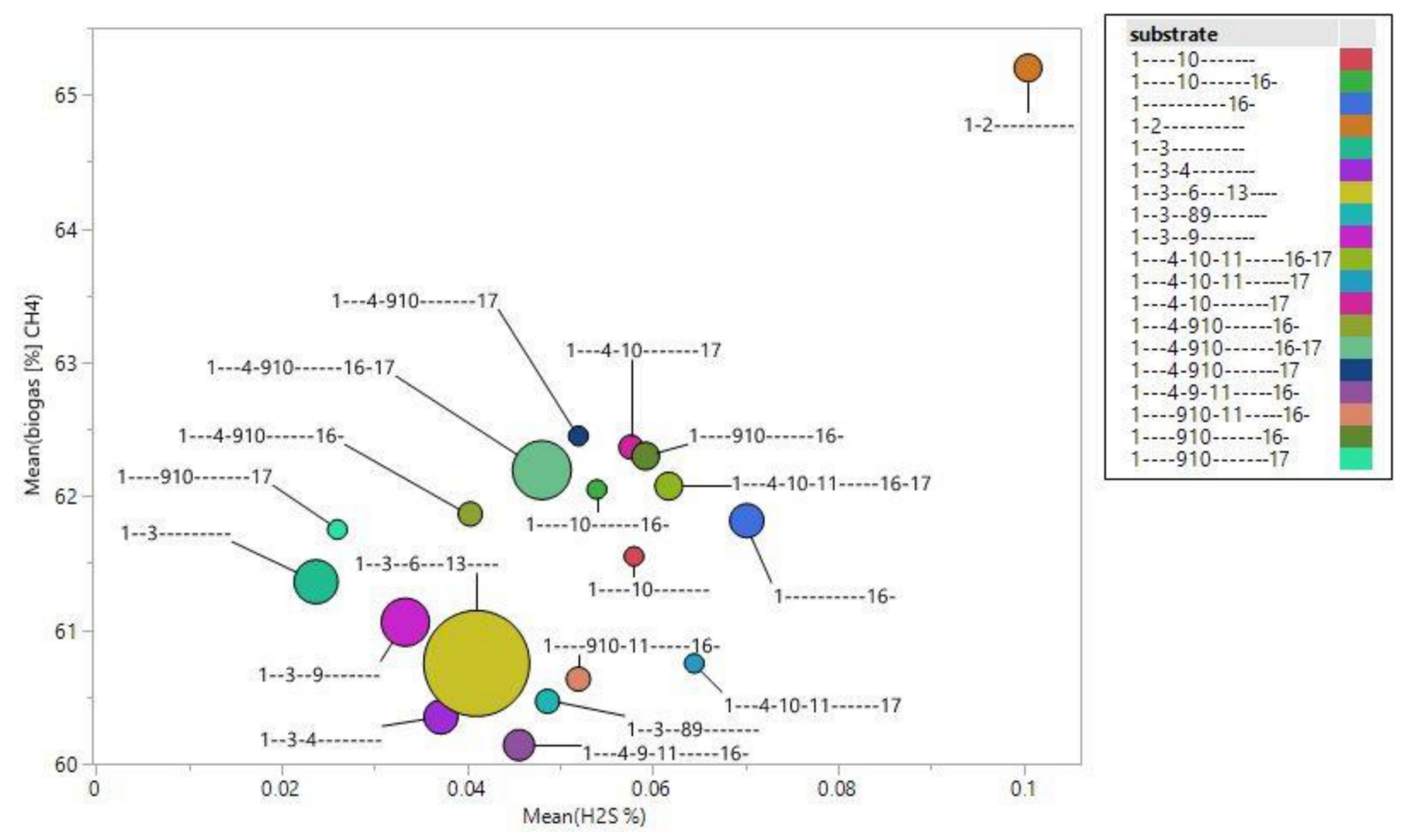

Figure 7. Quadrant I—suitable substrates.

\subsection{Unsuitable Substrates}

Based on this, we can select substrates of lower quality, in our case 11 substrates located in quadrant IV (Figure 8). The size of the bubble indicates the two most common substrates: 1-2-3-56 and 1-2-3-6-, which reach average values of $\mathrm{CH}_{4}$ at $58 \%$ and $\mathrm{H}_{2} \mathrm{~S}$ at $0.16 \%$. The worst (highest) values of $\mathrm{H}_{2} \mathrm{~S}$ were achieved by the substrate 1-2-3-567 with a value of $0.2 \%$, which also achieved the worst (lowest) values of $\mathrm{CH}_{4}$ at the level of $55.7 \%$.

Subsequently, we dealt with the analysis of individual components of which the substrates thus defined were composed. We found that the selection of stable substrates excluded two components from the analysis: $12-$ Other $4[\mathrm{~kg}]$ and 14 -Corn chips silage $[\mathrm{kg}]$, which may indicate that the variability in the achieved values of substrates may be caused by these two components, but this cannot be finally confirmed without further investigation. 


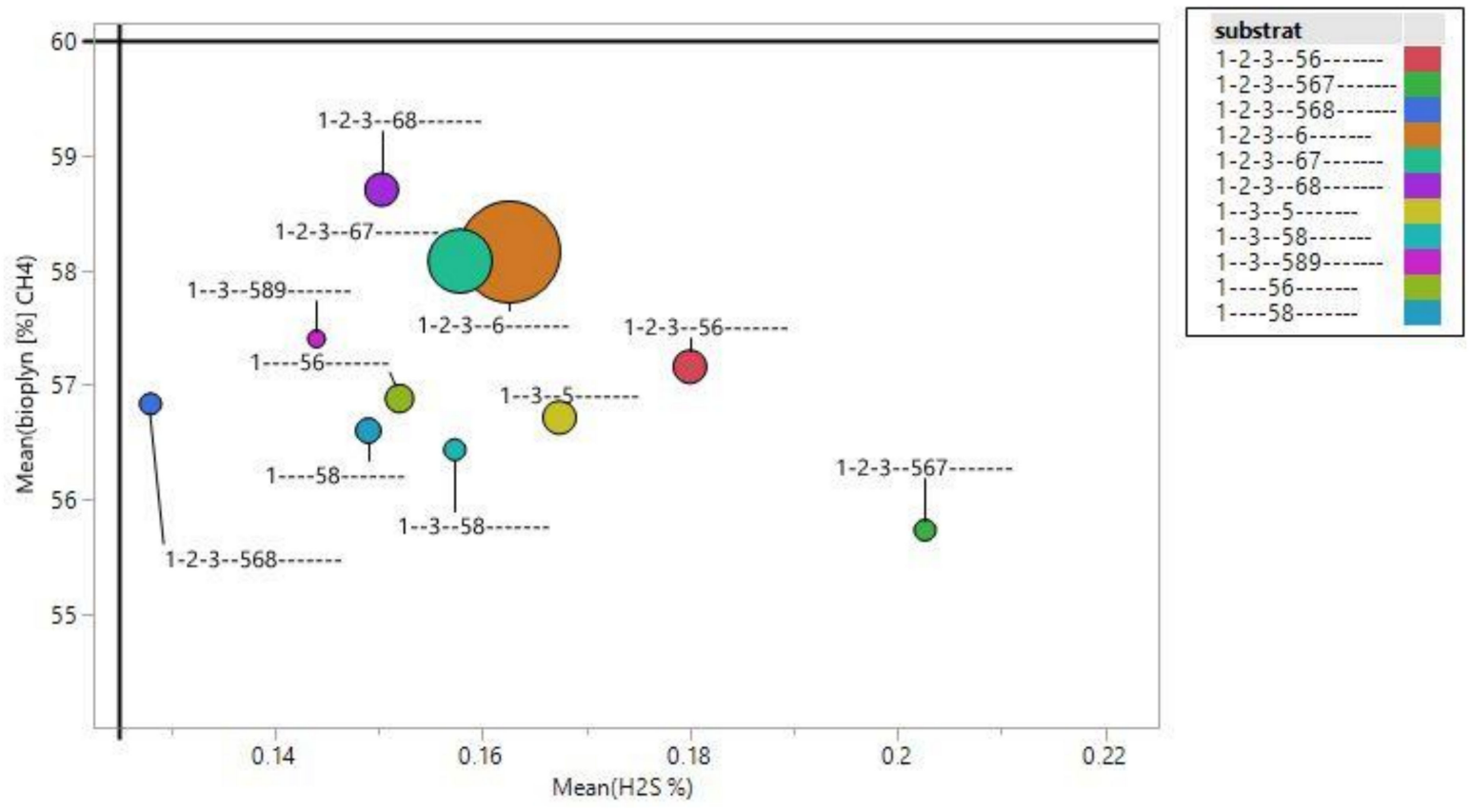

Figure 8. Quadrant IV—unsuitable substrates.

By selecting suitable relatively stable substrates, we found that of the 17 components analyzed, the next four components were not in the substrates:

- $\quad 5$-Rye $[\mathrm{kg}]$

- $\quad$ 7-Oil [kg]

- $\quad 12-$ Other $4[\mathrm{~kg}]$

- $\quad$ 14-Corn chips silage $[\mathrm{kg}]$

By examining and comparing the percentage of components of both types of substrates, we came to the conclusion that the most significant difference is in the case of component No. 2-Sorghum silage. For suitable substrates, it was on average $1.29 \%$, but for unsuitable substrates its share reached up to $12.07 \%$ (see Table 3).

Table 3. The average proportion of individual components of suitable and unsuitable substrates.

\begin{tabular}{ccccc}
\hline Folder & \multicolumn{2}{c}{ Mean Suitable Substrates } & \multicolumn{2}{c}{ Mean Unsuitable Substrates } \\
\cline { 2 - 5 } & {$[\mathbf{k g}]$} & {$[\%]$} & {$[\mathbf{k g}]$} & {$[\%]$} \\
\hline 1-Corn silage/Maize silage & 29,154 & $61.47 \%$ & 29,913 & $56.07 \%$ \\
2-Sorghum silage & 404.228 & $1.29 \%$ & 6464.32 & $12.07 \%$ \\
3-Receiving tank & 8799.06 & $18.82 \%$ & $12,651.5$ & $22.45 \%$ \\
4-Pastry & 436.04 & $0.87 \%$ & 0 & $0.00 \%$ \\
5-Rye & 0 & $0.00 \%$ & 2686.06 & $5.74 \%$ \\
6-Manure & 414.228 & $0.90 \%$ & 1634.7 & $3.01 \%$ \\
7-Oil & 0 & $0.00 \%$ & 34.5455 & $0.06 \%$ \\
8-Juniper & 133.02 & $0.26 \%$ & 229,848 & $0.49 \%$ \\
9-Other 1 & 894.698 & $1.67 \%$ & 47.2727 & $0.10 \%$ \\
10-Other 2 & 585.369 & $1.21 \%$ & 0 & $0.00 \%$ \\
11-Other 3 & 158.121 & $0.28 \%$ & 0 & $0.00 \%$ \\
12-Other 4 & 0 & $0.00 \%$ & 0 & $0.00 \%$ \\
13-Haylage & 1885.1 & $3.95 \%$ & 0 & $0.00 \%$ \\
14-Corn chips silage & 0 & $0.00 \%$ & 0 & $0.00 \%$ \\
15-CCM (Corn Cob Mix) & 32.7517 & $0.06 \%$ & 0 & $0.00 \%$ \\
16-Pasteurized biodegradable waste & 4503.22 & $8.12 \%$ & 0 & $0.00 \%$ \\
17-Fruits/vegetables & 556.705 & $1.10 \%$ & 0 & $0.00 \%$ \\
\hline biogas [\%] CH4 & & 61.3047 & & 57.8091 \\
H2S [\%] & 0.0453 & & 0.1611 &
\end{tabular}

3-The receiving tank includes: whey, oils and fats, pasteurized restaurant waste, fruit and vegetables, fish, meat, grain, food, chips, pastries, dough, flour. 


\section{Conclusions}

In the presented paper, we analyzed the operating parameters of a biogas plant in terms of the quality of biogas produced from a mixture of kitchen waste and agricultural crops. Based on data obtained over 2.5 years, it was found that the quality of biogas varies significantly. In the research, we used a statistical evaluation of all inputs to the biogas plant in order to identify the impact of individual components on the quality of biogas. Analysis of input variables defined 17 different components entering 125 types of substrates. More detailed analysis confirmed significant differences in the proportion of methane and unwanted hydrogen sulfide in the biogas produced from the investigated substrates. However, due to the nature of the inputs-mixed kitchen waste-a significant dispersion of the achieved outputs was also identified at the level of individual substrates. Within the research, 63 substrates meeting the stability criteria were selected. The result of the analysis is the definition of 20 suitable and 11 unsuitable substrates for the process of quality biogas production in the investigated plant. The influence of component No. 2-Sorghum silage, which is $1.29 \%$ on average with suitable substrates, can be considered as a statistically significant result, but with unsuitable substrates its share reaches $12.07 \%$.

The research results show that Sorghum silage in combination with food waste is statistically responsible for the increased share of $\mathrm{H}_{2} \mathrm{~S}$ in biogas. As only the operating parameters of the biogas plant were analyzed in the research, for more relevant results it would be necessary to verify this fact by longer-term specialized research. Following this, we plan to conduct research aimed at verifying the hypothesis that Sorghum silage increases the share of $\mathrm{H}_{2} \mathrm{~S}$ in biogas produced from heterogeneous inputs based on food waste. The results of the presented research will be used to determine the composition of the input component of food waste. The used input database makes it possible to determine the composition of the waste depending on the season and the waste supplier. In the laboratory environment CE 642, different proportions of food waste and Sorghum silage will be tested and the amount of $\mathrm{H}_{2} \mathrm{~S}$ in the produced biogas will be analyzed. The results of the research in the form of critical values will be tested in real operation in order to confirm or reject the hypothesis. If this hypothesis is confirmed, it would be possible to reduce the $\mathrm{H}_{2} \mathrm{~S}$ content in biogas and reduce the corrosivity of the produced biogas.

Due to the time limits of storage of imported waste, it was necessary to perform a statistical analysis of the impact of substrates used in this biogas plant on the quality of biogas. The results of the analysis will allow the operator to create a logistics plan for the supply of the biogas plant optimizing the quality of production.

Author Contributions: Conceptualization, M.T. and D.K.; methodology, M.T.; software, M.T.; validation, M.T., D.K. and P.T.; formal analysis, L'.G.; investigation, M.T.; resources, L'.G.; data curation, P.T.; writing—original draft preparation, D.K.; writing — review and editing, P.T.; visualization, M.T.; supervision, P.T.; project administration, D.K.; funding acquisition, D.K. All authors have read and agreed to the published version of the manuscript.

Funding: This research was funded by Scientific Grant Agency of the Ministry of Education, Science, Research and Sport of the Slovak Republic (VEGA), grant number 1/0509/18.

Conflicts of Interest: The authors declare no conflict of interest. The funders had no role in the design of the study; in the collection, analyses, or interpretation of data; in the writing of the manuscript, or in the decision to publish the results.

\section{References}

1. Scarlat, N.; Dallemand, J.-F.; Fahl, F. Biogas: Developments and perspectives in Europe. Renew. Energy 2018, 129, 457-472. [CrossRef]

2. Banja, M.; Jégard, M.; Motola, V.; Sikkema, R. Support for biogas in the EU electricity sector-A comparative analysis. Biomass Bioenergy 2019, 128. [CrossRef]

3. CBA (Česká Bioplynová Asociace). National Technology Platform for Biogas. 2019. Available online: https://www.czba.cz/ (accessed on 1 March 2020). 
4. $\quad$ EBA (European Biogas Association). EBA Statistical Report 2018. Renewable Energy House. 2019. Available online: www.europeanbiogas.eu (accessed on 1 April 2019).

5. Energie Portal. Biogas Station in Slovakia. 2017. Available online: https://www.energie-portal.sk/Dokument/ bioplynove-stanice-v-sr-100191.aspx (accessed on 3 January 2017).

6. Energie Portal. Additional Subsidies from Eurofunds go to Biogas Plants. 2019. Available online: https://www.energie-portal.sk/Dokument/na-bioplynove-stanice-smeruju-dalsie-dotaciez-eurofondov-105302.aspx (accessed on 25 July 2017).

7. Appunn, K. Bioenergy-The Troubled Pillar of the Energiewende. 2016. Available online: https://www. cleanenergywire.org/dossiers/bioenergy-germany (accessed on 30 September 2016).

8. Angelidaki, I.; Treu, L.; Tsapekos, P.; Luo, G.; Campanaro, S.; Wenzel, H.; Kougias, P.G. Biogas upgrading and utilization: Current status and perspectives. Biotechnol. Adv. 2018, 36, 452-466. [CrossRef] [PubMed]

9. Cano-Santana, P.I.; Colón, J.; Ramírez, M.; Lafuente, F.J.; Gabriel, D.; Cantero, D. Life cycle assessment of different physical-chemical and biological technologies for biogas desulfurization in sewage treatment plants. J. Clean. Prod. 2018, 181, 663-674. [CrossRef]

10. Abatzoglou, N.; Bolvin, S. A review of biegas purification processes. Biofuels Bioprod. Biorefin. 2009, 3, 42-47. [CrossRef]

11. Salehi, R.; Chaiprapat, $\mathrm{S}$. Single-/triple-stage biotrickling filter treating a $\mathrm{H}_{2} \mathrm{~S}$-rich biogas stream: Statistical analysis of the effect of empty bed retention time and liquid recirculation velocity. J. Air Waste Manag. Assoc. 2019, 69, 1429-1437. [CrossRef] [PubMed]

12. Andriani, D.; Rajani, A.; Santosa, A.; Saepudin, A.; Wresta, A.; Atmaja, T.D. A review on biogas purification through hydrogen sulphide removal. IOP Conf. Ser. Earth Environ. Sci. 2020, 483, 1-11. Available online: https://iopscience.iop.org/article/10.1088/1755-1315/483/1/012034/pdf (accessed on 1 June 2020). [CrossRef]

13. Afridi, Z.U.R.; Qammar, N.W. Technical Challenges and Optimization of Biogas Plants. CBEN 2020, 7, 119-129. [CrossRef]

14. Petersson, A. Biogas cleaning. In The Biogas Handbook; Wellinger, A., Murphy, J., Baxter, D., Eds.; Woodhead Publishing: Cambridge, UK, 2013; pp. 329-341. [CrossRef]

15. Smatanova, M.; Biogas Station. Central Institute for Supervising and Testing in Agriculture. Available online: http://eagri.cz/public/web/file/214721/_2_BPS.pdf (accessed on 28 September 2020).

16. Bernat, K.; Kulikowska, D.; Wojnowska-Baryła, I.; Zaborowska, M.; Pasieczna-Patkowska, S. Thermophilic and mesophilic biogas production from PLA-based materials: Possibilities and limitations. Waste Manag. 2021, 119, 295-305. [CrossRef]

17. Zaefferer, M.; Gaida, D.; Bartz-Beielstein, T. Multi-fidelity modeling and optimization of biogas plants. Appl. Soft Comput. 2016, 48, 13-28. [CrossRef]

18. Batstone, D.J.; Keller, J.; Angelidaki, I.; Kalyuzhnyi, S.V.; Pavlostathis, S.G.; Rozzi, A.; Sanders, W.T.M.; Siegrist, H.; Vavilin, V.A. The IWA Anaerobic Digestion Model No. 1 (ADM1). Water Sci. Technol. 2002, 45, 65-73. [CrossRef]

19. Olubunmi, O.A.; Abiodun, E.A.; Adesina, A.O.; Pourianejad, S.; Zentner, A.; Dornack, C. Stabilization of anaerobic co-digestion of biowaste using activated carbon of coffee ground biomass. Bioresour. Technol. 2021, 319. [CrossRef]

20. Gaida, D.; Wolf, C.; Bongards, M.; Bäck, T. Matlab toolbox for biogas plant modelling and optimization. Prog. Biogas II 2011, 2, 67-70.

21. Schoen, M.A.; Sperl, D.; Gadermaier, M.; Goberna, M.; Franke-Whittle, I.; Insam, H.; Ablinger, J.; Wett, B. Population dynamics at digester overload conditions. Bioresour. Technol. 2009, 100, 5648-5655. [CrossRef] [PubMed]

22. Wolf, C.; McLoone, S.; Bongards, M. Biogas plant optimization using genetic algorithms and particle swarm optimization. In Proceedings of the 16th IET Irish Signals and Systems Conference 2008, Galway, Ireland, 18-19 June 2008; pp. 244-249.

23. Ziegenhirt, J.; Bartz-Beielstein, T.; Flasch, O.; Konen, W.; Zaefferer, M. Optimization of biogas production with computational intelligence a comparative study. In Proceedings of the IEEE Congres on Evolutionary Computation, Barcelona, Spain, 18-23 July 2010; pp. 1-8.

24. Hansen, N.; Ostermeier, A. Adapting arbitrary normal mutation distributions in evolution strategies: The covariance matrix adaptation. In Proceedings of the 1996 IEEE International Conference on Evolutionary Computation, Nagoya, Japan, 20-22 May 1996; pp. 312-317. 
25. Hansen, N. The CMA evolution strategy: A comparing review. In Towards a New Evolutionary Computation, Studies in Fuzziness and Soft Computing; Lozano, J.A., Larranaga, P., Inza, I., Bengoetxea, E., Eds.; Springer: Berlin/Heidelberg, Germany, 2006; Volume 192, pp. 75-102.

26. Storn, R.; Price, K. Differential evolution-A simple and efficient heuristic for global optimization over continuous spaces. J. Glob. Optim. 1997, 11, 341-359. [CrossRef]

27. Bartz-Beielstein, T.; Parsopoulos, K.E.; Vrahatis, M.N. Design and analysis of optimization algorithms using computational statistics. Appl. Numer. Anal. Comput. Math. 2004, 1, 413-433. [CrossRef]

28. Forrester, A.I.; Sóbester, A.; Keane, A.J. Multi-fidelity optimization via surrogate modelling. Proc. R. Soc. A Math. Phys. Eng. Sci. 2007, 463, 3251-3269. [CrossRef]

29. Cressie, N. The origins of kriging. Math. Geol. 1990, 22, 239-252. [CrossRef]

30. Matheron, G. Principles of geostatistics. Econ. Geol. 1963, 58, 1246-1266. [CrossRef]

31. Jones, D.; Schonlau, M.; Welch, W. Efficient global optimization of expensive black-Box functions. J. Glob. Optim. 1998, 13, 455-492. [CrossRef]

32. Drucker, H.; Burges, C.J.C.; Kaufman, L.; Smola, A.J.; Vapnik, V. Support Vector Regression Machines; Mozer, M., Jordan, M.I., Petsche, T., Eds.; NIPS; MIT Press: Cambridge, MA, USA, 1996; pp. 155-161.

33. Breiman, L. Random Forests. Mach. Learn. 2001, 45, 5-32. [CrossRef]

34. Friedman, J.H. Multivariate adaptive regression splines. Ann. Stat. 1991, 19, 1-141. [CrossRef]

35. Allegue, L.B.; Hinge, J. Biogas upgrading Evaluation of methods for $\mathrm{H}_{2} \mathrm{~S}$ removal. Available online: https://www.teknologisk.dk/_/media/60599_Biogas\%20upgrading.\%20Evaluation\%20of\%20methods\% 20for\%20H2S\%20removal.pdf (accessed on 1 December 2014).

36. Kapoor, R.; Ghosh, P.; Kumar, M.; Vijay, V.K. Evaluation of biogas upgrading technologies and future perspectives: A review. Environ. Sci. Pollut. Res. 2019, 26, 11631-11661. [CrossRef]

37. Agneessens, L.M.; Ottosen, L.D.M.; Voigt, N.V.; Nielsen, J.L.; de Jonge, N.; Fischer, C.H.; Kofoed, M.V.W. In-situ biogas upgrading with pulse $\mathrm{H} 2$ additions: The relevance of methanogen adaption and inorganic carbon level. Bioresour. Technol. 2017, 233, 256-263. [CrossRef]

38. Boontawee, S.; Koonaphapdeelert, S. In-situ biomethane enrichment by recirculation of biogas channel digester effluent using gas stripping column. Energy Procedia 2016, 89, 78-84. [CrossRef]

39. Marin, D.; Vega, M.; Lebrero, R.; Munoz, R. Influence of the diffuser type and liquid-to-biogas ratio on biogas upgrading performance in an outdoor pilot scale high rate algal pond. J. Water Process Eng. 2020, 37. [CrossRef]

40. Armah, E.K.; Chetty, M.; Deenadayalu, N. Biogas production from sugarcane bagasse with South African industrial wastewater and novel kinetic study using response surface methodology. Sci. Afr. 2020, 10. [CrossRef]

41. Marin, D.; Carmona-Martinez, A.A.; Lebrero, R.; Munoz, R. Optimization of a chemical scrubbing process based on a Fe-EDTA-carbonate based solvent for the simultaneous removal of $\mathrm{CO}_{2}$ and $\mathrm{H}_{2} \mathrm{~S}$ from biogas. Fuel 2020, 275. [CrossRef]

42. Jamalluddin, M.F.; Zainol, N.; Sharif, N.S.A.M. Troubleshooting on biogas production by using factorial analysis in sewage treatment plant (STP). Mater. Today Proc. 2020. [CrossRef]

Publisher's Note: MDPI stays neutral with regard to jurisdictional claims in published maps and institutional affiliations.

(C) 2020 by the authors. Licensee MDPI, Basel, Switzerland. This article is an open access article distributed under the terms and conditions of the Creative Commons Attribution (CC BY) license (http://creativecommons.org/licenses/by/4.0/). 